\title{
HUBUNGAN ANTARA ASUPAN MAKANAN, STRES, DAN AKTIVITAS FISIK DENGAN HIPERTENSI PADA USIA MENOPAUSE DI PUSKESMAS PANGKALAN LADA
}

\author{
${ }^{1}$ Eko Sari Ajiningtyas ${ }^{2}$ Siti Fatimah ${ }^{3}$ Rahmayanti \\ ${ }^{123}$ STIKES Borneo Cendekia Medika Pangkalan Bun \\ ${ }^{1}$ Email : mahardikagunardi@gmail.com
}

\begin{abstract}
ABSTRAK
Kasus hipertensi paling banyak diderita pada kelompok umur $>45$ tahun. Jika dibandingkan dengan pria, ternyata wanita lebih banyak menderita hipertensi. Di Kalimantan Tengah didapatkan angka prevalensi $6 \%$ dari pria dan $11 \%$ pada wanita. Hipertensi pada usia menopause merupakan salah satu penyebab utama morbiditas dan mortalitas pada wanita. Tujuan dari penelitian ini untuk menganalisis faktor asupan makanan, stres, dan aktivitas fisik terhadap hipertensi pada usia menopause di Puskesmas Pangkalan Lada. Penelitian ini merupakan jenis penelitian kuantitatif dengan menggunakan desain cross sectional. Sampel pada penelitian ini yaitu sebanyak 50 orang. Penelitian dilakukan pada bulan Mei - Juni 2017. Pengukuran variabel-variabelnya dilakukan hanya satu kali dengan data primer dan sekunder. Variabel penelitian meliputi hipertensi, asupan lemak, asupan natrium, stres, dan aktivitas fisik. Analisis data pada penelitian ini menggunakan analisis univariat, bivariat menggunakan uji Spearman rank, dan multivariat menggunakan uji Regresi Logistik. Hasil penelitian menunjukkan ada hubungan yang bermakna antara aktivitas fisik ( $\mathrm{p}=0,017)$, stres $(\mathrm{p}=0,001)$, asupan lemak $(\mathrm{p}=0,001)$, asupan natrium $(\mathrm{p}=0,001)$ terhadap hipertensi pada usia menopause di Puskesmas Pangkalan Lada. Hasil regresi logistik menunjukkan bahwa asupan natrium memiliki tingkat resiko lebih tinggi terhadap hipertensi $(\mathrm{p}=0,021)$ jika dibandingkan dengan faktor yang lainnya. Sebagian besar wanita yang telah menopause menderita hipertensi sebanyak $70 \%$. Terdapat hubungan yang signifikan antara faktor stress, aktivitas fisik, asupan lemak, dan asupan natrium dengan hipertensi pada usia menopause di Puskesmas Pangkalan Lada. Analisis multivariate diperoleh hasil hanya satu faktor asupan natrium yang paling dominan mempengaruhi hipertensi pada usia menopause.
\end{abstract}

Kata Kunci : Hipertensi, asupan makanan, stres, aktivitas fisik, menopause.

RELATIONSHIP BETWEEN FOOD INTAKE, STRESS, AND PHYSICAL ACTIVITY WITH HYPERTENSION IN MENOPAUSE AGE IN PANGKALAN PUBLIC HEALTH

\section{ABSTRACT}

Most cases of hypertension are suffered in the age group $>45$ years. When compared with men, it turns out that women suffer more hypertension. In Central Kalimantan, the prevalence rate is $6 \%$ for men and $11 \%$ for women. Hypertension at menopause is one of the main causes of morbidity and mortality in women. The purpose of this study was to analyze the factors of food intake, stress, and physical activity towards 
hypertension at menopause at Pangkalan Lada Health Center. This research is a type of quantitative research using cross sectional design. The sample in this study were as many as 50 people. The study was conducted in May - June 2017. Measurement of the variables was carried out only once with primary and secondary data. Research variables include hypertension, fat intake, sodium intake, stress, and physical activity. Data analysis in this study used univariate analysis, bivariate using the Spearman rank test, and multivariate using the Logistic Regression test. The results showed a significant relationship between physical activity $(p=0.017)$, stress $(p=0.001)$, fat intake $(p=0.001)$, sodium intake $(p=0.001)$ against hypertension at menopause at the Pangkalan Lada Health Center. The logistic regression results show that sodium intake has a higher risk for hypertension $(p=0.021)$ when compared with other factors. Most women who have menopause suffer from hypertension as much as $70 \%$. There is a significant relationship between stress factors, physical activity, fat intake, and sodium intake with hypertension at the age of menopause at the Pangkalan Lada Health Center. Multivariate analysis showed that only one sodium intake factor was the most dominant influence on hypertension at menopause.

Keywords: Hypertension, food intake, stress, physical activity, menopause

\section{PENDAHULUAN}

Penyakit kardiovaskular merupakan salah satu penyebab kematian terbesar di dunia, yaitu sekitar 17 juta kematian per tahun. Jumlah prevalensi tersebut yang penyumbang angka tertinggi adalah penyakit hipertensi dengan jumlah 9,4 juta kematian per tahun. Hipertensi bertanggung jawab setidaknya $45 \%$ terhadap komplikasi akibat penyakit jantung (WHO, 2013). Jumlah total orang dewasa dengan hipertensi pada tahun 2025 diperkirakan meningkat menjadi 1,56 miliar. Mengidentifikasi karakteristik dan faktor risiko yang dapat dimodifikasi penyebab hipertensi penting bagi kesehatan masyarakat dan kedokteran klinis (Kearney et al, 2005).

Hipertensi menjadi salah satu masalah kesehatan masyarakat yang terjadi di negara maju maupun negara berkembang. Hipertensi adalah penyebab kematian nomor 3 setelah stroke $(15,4 \%)$ dan tuberkulosis $(7,5$ $\%$ ), yakni mencapai $6,8 \%$ dari populasi kematian pada semua umur di Indonesia (Depkes RI, 2008). Penelitian di Nepal yang dilakukan oleh (Chataut, Adhikari, \& Sinha, 2011) menemukan bahwa hipertensi dipengaruhi oleh jenis kelamin, usia, tingkat pendidikan, aktivitas fisik, indeks massa tubuh (IMT), rokok, dan konsumsi alkohol.

Hipertensi merupakan suatu keadaan ketika tekanan darah di pembuluh darah meningkat secara kronis. Tekanan darah sistolik lebih dari 140 mmHg dan tekanan darah diastolik lebih dari $90 \mathrm{mmHg}$. Hal tersebut dapat terjadi karena jantung bekerja lebih keras memompa darah untuk memenuhi kebutuhan oksigen dan nutrisi tubuh (Riskesdas, 2013).

Banyak pasien hipertensi dengan tekanan darah tidak terkontrol dan jumlahnya terus meningkat. Peningkatan tekanan darah yang berlangsung dalam jangka waktu lama (persisten) dapat menimbulkan kerusakan pada ginjal (gagal ginjal), jantung (penyakit jantung koroner) dan 
otak (menyebabkan stroke) bila tidak dideteksi secara dini dan mendapat pengobatan yang memadai. (Kemenkes RI, 2014).

Penelitian Rahayu (2014), menunjukkan ada hubungan antara usia menopause dengan kejadian hipertensi di Desa Kutaliman Kecamatan Kedungbanteng Kabupaten Banyumas (berdasarkan hasil perhitungan diperoleh nilai $P$ (Assymp.Sign $)=0,036$ yang berarti nilai $P<$

$\alpha(0,05)$. Bagi wanita usia menopause diharapkan dapat menyadari pentingnya kesehatan dengan menerapkan pola hidup sehat dan tetap melakukan pengukuran tekanan darah secara rutin.

Izumi et al (2007), melakukan survei medis di barat laut Cina, terhadap 150 perempuan pascamenopause, dan korelasi positif ditemukan antara periode pascamenopause baik tekanan darah sistolik maupun tekanan darah diastolik. Tekanan darah, usia saat menopause, dan periode pascamenopause yang tidak signifikan berhubungan dengan indeks massa tubuh, aktivitas renin plasma, laju filtrasi glomerulus, atau nilai-nilai ekskresi natrium dan kalium.

Penelitian dari Sase (2013), hasil uji menunjukkan bahwa terdapat hubungan bermakna antara asupan natrium dengan tekanan darah sistolik ( $\mathrm{r}=0,514, p=0,000)$, namun tidak terdapat hubungan bermakna asupan natrium dengan tekanan darah diastolik $(\mathrm{r}=0,195, \quad p=0,108)$. Tidak terdapat hubungan yang bermakna $(p>0,05)$ durasi aktivitas fisik dengan peningkatan tekanan darah sistolik maupun diastolik.

Penelitian lain dari Widyaningrum (2012) diperoleh hasil Pada variabel tingkat konsumsi terdapat 3 (tiga) variabel yang berhubungan secara signifikan dengan kejadian hipertensi yaitu variabel lemak $(p=0,010)$, natrium $(p=0,004)$, serat $(p=0,000)$, sedangkan variabel karbohidrat tidak berhubungan secara signifikan (nilai $p$ $(0,599)>\alpha(0,05)$ dengan kejadian hipertensi. Berdasarkan hasil tersebut, diketahui bahwa tingkat konsumsi lemak responden jauh melebihi kecukupan gizi yang dianjurkan untuk dikonsumsi oleh tubuh mereka.

Studi pendahuluan yang dilakukan oleh peneliti dengan wawancara terhadap beberapa wanita menopause usia $\geq 55$ tahun di puskesmas Pangkalan Lada, wanita-wanita tersebut belum mengetahui terjadinya perubahan fisiologis pada masa ini. Terjadinya perubahan tersebut dapat menyebabkan penurunan fungsi tubuh yang secara tidak langsung akan meningkatkan resiko terhadap hipertensi. Faktor yang dapat mempengaruhi meliputi asupan makanan yang tidak sehat seperti asupan dengan kadar lemak berlebih, asupan garam berlebih, kurangnya aktifitas tubuh yang lebih aktif, dan perasaan tertekan yang dapat menimbulkan stres. Faktor-faktor tersebut sangat berperan terhadap timbulnya hipertensi, terutama pada wanita menopause yang telah berkurang ketahanan tubuhnya.

Paparan fenomena diatas menunjukkan banyaknya kasus hipertensi pada wanita usia menopause, disebabkan oleh karena kualitas asupan makanan, masalah psikologis, dan gaya hidup yang dapat meningkatkan hipertensi. Maka peneliti ingin melakukan penelitian dengan judul "Hubungan Asupan Makanan, stres, dan aktivitas fisik dengan Hipertensi Pada Usia Menopause". 


\section{Konsep Hipertensi}

Menurut Soeparman (2001) hipertensi terjadi apabila tekanan darah lebih dari 140/90 mmHg. Hipertensi berkaitan dengan kenaikan tekanan sistolik atau tekanan diastolik atau tekanan keduanya. Hipertensi dapat didefinisikan sebagai tekanan darah tinggi persisten dimana tekanan sistoliknya di atas $140 \mathrm{mmHg}$ dan tekanan diastolik di patas $90 \mathrm{mmHg}$. Dikatakan hipertensi apabila terjadi peningkatan tekanan darah secara abnormal dan terus-menerus pada beberapa kali pemeriksaan tekanan darah. Pengukuran yang pertama kali belum dapat memastikan adanya hipertensi, akan tetapi dapat merupakan petunjuk untuk dilakukan observasi lebih lanjut.

Menurut Wijaya (2013) patofisiologi terhadap hipertensi esensial terus berkembang. Karena belum terdapat jawaban yang memuaskan penyebab pasti dari hipertensi esensial, yang dapat menerangkan terjadinya peningkatan tekanan darah. Tekanan darah dipengaruhi oleh curah jantung dan tahanan perifer, sehingga semua faktor yang mempengaruhi curah jantung dan tahanan perifer akan mempengaruhi tekanan darah: Tekanan Darah $=$ Curah Jantung $\times$ Tahanan Perifer

Meningkatnya tekanan darah di dalam arteri bisa terjadi melalui beberapa cara yaitu jantung memompa lebih kuat sehingga mengalirkan lebih banyak cairan pada setiap detiknya arteri besar kehilangan kelenturannya dan menjadi kaku sehingga mereka tidak dapat mengembang pada saat jantung memompa darah melalui arteri tersebut. Darah pada setiap denyut jantung dipaksa untuk melalui pembuluh yang sempit daripada biasanya dan menyebabkan naiknya tekanan. Inilah yang terjadi pada usia lanjut, dimana dinding arterinya telah menebal dan kaku karena arterioskelierosis.

Menurut Bustan (2015) faktor risiko yang dapat berpengaruh pada kejadian hipertensi, antara lain umur, ras/suku, geografis, jenis kelamin, obesitas, stres, diet tinggi garam, diabetes melitus, alkohol, merokok, konsumsi kopi, dan penggunaan pil KB. Faktor resiko adalah faktor-faktor atau keadaan-keadaan yang mempengaruhi perkembangan suatu penyakit atau status kesehatan. Istilah mempengaruhi mengandung pengertian menimbulkan risiko lebih besar pada individu atau masyarakat untuk terjangkitnya suatu penyakit atau terjadinya status kesehatan tertentu.

Andria (2013) mengungkapkan bahwa banyak faktor yang berperan untuk terjadinya hipertensi meliputi faktor risiko yang tidak dapat dikendalikan seperti keturunan, jenis kelamin, rasdan usia, dan faktor risiko yang dapat dikendalikan yaitu obesitas, kurangolah raga atau aktivitas, merokok, minumkopi, sensitivitas natrium, kadar kalium rendah, alkoholisme, stress.

Umur. Mempengaruhi tekanan darah yang cenderung akan meningkat seiring dengan bertambahnya usia, pada umumnya penderita hipertensi adalah orang-orang yang berusia 40 tahun, namun pada saat ini tidak menutup kemungkinan diderita oleh orang yang berusia lebih muda.

Jenis kelamin. Wanita penderita hipertensi dua kali lebih banyak daripada pria tanpa kerusakan jantung dan pembuluh darah. Sebelum menopause wanita mempunyai 
kecenderungan menderita hipertensi lebih sedikit dibanding pada keadaan apabila wanita telah mengalami menopause (Fadi at al, 2014).

\section{Riwayat keluarga / keturunan}

Hipertensi cenderung untuk diturunkan di dalam keluarga. Seseorang yang memiliki riwayat keluarga hipertensi akan meningkatkan risiko hipertensi dua kali lebih besar dibandingkan dengan orang yang tidak memiliki riwayat hipertensi. Riwayat hipertensi merupakan faktor resiko pada hipertensi primer dan merupakan faktor resiko yang tidak dapat dikontrol. Faktor genetik pada hipertensi esensial banyak dijumpai pada penderita kembar monozigot daripada heterozigot, apabila salah satu diantaranya menderita hipertensi, menyokong bahwa faktor genetik mempunyai peran terhadap terjadinya hipertensi (Soeparman, 2001).

\section{Konsep Asupan Makanan}

Lemak merupakan simpanan energi bagi manusia. Lemak dalam bahan makanan berfungsi sebagai sumber energi, menghemat protein dan thiamin, membuat rasa kenyang lebih lama (karena proses pencernaan lemak lebih lama), pemberi cita rasa dan keharuman yang lebih baik. Fungsi lemak dalam tubuh adalah sebagai zat pembangun, pelindung kehilangan panas tubuh, penghasil asam lemak esensial, pelarut vitamin $\mathrm{A}, \mathrm{D}, \mathrm{E}, \mathrm{K}$, sebagai prekusor dari prostaglandin yang berperan mengatur tekanan darah, denyut jantung dan lipofisis (Almatsier, 2009).

Natrium adalah kation utama dalam cairan ekstraseluler tubuh yang mempunyai fungsi menjaga keseimbangan cairan dan asam basa tubuh, serta berperan dalam transmisi syaraf dan kontraksi otot.
(Almatiser, 2009).

\section{Konsep Stres}

Pengertian stres dalam kamus psikologi Chaplin (2000), stres merupakan keadaan tertekan, baik secara fisik maupun psikologis. Keadaan yang membuat tertekan ini karena adanya kebutuhan dan dorongan yang tidak sesuai dengan kenyataan yang diharapkan, serta respon masing-masing individu yang berbeda. Artinya stressor (sesuatu yang dapat membuat stres/pemicu stres) yang sama bisa ditanggapi secara berbeda oleh dua atau lebih individu yang berbeda. Jelas itu berkaitan dengan persepsi, tanggapan (response), dari masing-masing individu. Tahapan sebelum seseorang mengalami stres, ia akan mengalami frustasi terlebih dahulu karena sesuatu yang menghambat tercapainya tujuan hidup itulah yang dinamakan frustasi. Frustasi yang terus menerus dan orang yang bersangkutan tidak mampu mengatasinya maka keadaan tersebut dinamakan stres.

\section{Gejala-Gejala Stres}

Gejala Biologis

Beberapa gejala biologis yang terjadi ketika seseorang mengalami stres antara lain peningkatan detak jantung, peningkatan kecepatan nafas, otot tegang terutama pada bagian lengan dan bahu, sakit kepala, berkeringat, sulit tidur, lemas, dan mudah lelah.

Gejala Psikologis

Dalam aspek kognitif : stres ditandai dengan adanya kekacauan pikiran, penurunan daya ingat, sulit berkonsentrasi, dan sulit membuat keputusan. 
Dalam aspek emosional : stres meliputi perasaan sedih atau depresi, cemas, takut, mudah tersinggung, dan ingin marah, khususnya ketika situasi dinilai berbahaya atau membuat frustasi.

Dalam aspek sosial : stres dapat merubah sikap seseorang terhadap orang lain. Agresif, kehilangan kepercayaan, kesepian / merasa sendiri, merasa tidak berguna lagi.

Faktor - faktor penyebab stres menurut Smeth (2004) Variabel dalam kondisi individu: umur, jenis kelamin, tempramen, faktor-faktor genetik, intelegensi, pendidikan, suku, kebudayaan, status ekonomi, dan kondisi fisik.Karakteristik kepribadian : introvert-ekstrovert, stabilitas emosi secara umum, tipe kepribadian A, ketabahan (hardiness), locus of control, kekebalan dan ketahanan.Variabel sosial-kognitif : dukungan sosial yang dirasakan, jaringan sosial, dan kontrol pribadi yang dirasakan.Hubungan dengan lingkungan sosial, dukungan sosial yang diterima, dan integrasi jaringan sosial.

\section{Konsep Aktivitas Fisik}

Aktivitas fisik adalah segala kegiatan atau aktivitas yang menyebabkan peningkatan energi oleh tubuh melampaui energi istirahat. Aktivitas fisik disebut juga aktivitas eksternal, yaitu sesuatu yang menggunakan tenaga atau energi untuk melakukan berbagai kegiatan fisik, seperti berjalan, berlari, dan berolahraga . Setiap kegiatan fisik membutuhkan energi yang berbeda menurut lamanya intensitas dan sifat kerja otot. Latihan fisik dapat meningkatkan kemampuan fungsional dan menurunkan kebutuhan oksigen otot jantung yang diperlukan pada setiap penurunan aktivitas fisik seseorang. Aktivitas fisik adalah gerakan yang dilakukan oleh otot tubuh dan sistem penunjangnya (Wilmore et al, 2004). Selama aktivitas fisik, otot memerlukan energi di luar metabolisme untuk bergerak. Banyaknya energi yang diperlukan bergantung pada seberapa berat pekerjaan yang dilakukan.

\section{Konsep Menopause}

Menopause merupakan satu istilah yang digunakan untuk menggambarkan perdarahan menstruasi terakhir dalam kehidupan seorang wanita dan mayoritas wanita mengalami menopause sekitar usia 51tahun, meskipun biasanya terjadi pada awal 45 tahun atau akhir 56 tahun (Abernethy, 2002).

Menurut Andrews (2009) menopause merupakan suatu istilah yang digunakan untuk menggambarkan perdarahan menstruasi terakhir dalam kehidupan seorang wanita. Menopause umumnya terjadi pada usia antara 45 hingga 58 tahun dan dapat terjadi lebih awal pada beberapa wanita.

\section{METODE PENELITIAN}

Penelitian ini merupakan jenis penelitian kuantitatif dengan menggunakan desain cross sectional, yaitu penulusuran sesaat, artinya pengukuran variabel-variabelnya dilakukan hanya satu kali. Untuk memperoleh informasi tentang variabel dependen dan variabel independen maka pengukurannya dilakukan bersama-sama pada saat penelitian dengan menggunakan kuesioner (Sugiyono,2014).

Populasi dalam penelitian ini adalah seluruh wanita penderita hipertensi pada usia menopause di Puskesmas Pangkalan Lada. Populasi dalam penelitian ini berjumlah 670 kasus. Sampel yang diambil dalam penelitian 
ini adalah wanita penderita hipertensi pada usia menopause di puskesmas Pangkalan Lada yang sesuai kriteria inklusi.

Teknik pengambilan sampel dalam penelitian ini menggunakan teknik Purposive Sampling, yaitu pengambilan sampel yang didasarkan pada suatu pertimbangan tertentu yang dibuat oleh peneliti, berdasarkan ciri atau sifat-sifat populasi yang sudah diketahui sebelumnya. (Sugiyono, 2013).

Adapun kriteria inklusi dan eksklusi dari sampel penelitian adalah sebagai berikut :

\section{Kriteria Inklusi}

Kriteria inklusi dalam penelitian ini adalah wanita penderita hipertensi pada usia menopause di wilayah kerja puskesmas Pangkalan Lada, wanita usia $>51$ tahun yang sudah mengalami menopause, merupakan pasien hipertensi dengan kasus lama, mampu berkomunikasi dengan baik, tidak menggunakan terapi hormon, bersedia menjadi responden, sedang berada di tempat pada saat penelitian dilaksanakan.

\section{Kriteria Eksklusi}

Kriteria ekslusi dalam penelitian ini adalah wanita yang berusia $>51$ tahun tetapi masih mengalami menstruasi, wanita menopause yang hipertensi dengan kasus baru, wanita menopause tetapi menggunakan terapi hormon, juga yang sudah tidak mampu berkomunikasi dengan baik.

\section{Waktu dan tempat penelitian}

Penelitian dilakukan pada bulan Mei-Juni 2017 di wilayah kerja Puskesmas

Pangkalan Lada.
Pada penelitian ini dilakukan uji statistik deskriptif untuk mengetahui distribusi frekuensi variabel yang mempengaruhi hipertensi pada usia menopause yang meliputi sub variable : Stres, asupan makanan (asupan lemak, asupan natrium), dan aktifitas fisik. Cara yang digunakan dengan cara data dikumpulkan kemudian dikelompokkan menurut jenis data masing-masing dan dimasukkan ke dalam tabel distribusi frekuensi.

Analisis bivariat merupakan analisis untuk mengetahui interaksi dua variabel, baik berupa komparatif, asosiatif maupun korelatif (Saryono 2008). Dalam analisis ini dilakukan dengan pengujian statistik yaitu dengan uji korelasi spearman untuk mengukur tingkat atau eratnya hubungan antara dua variabel yaitu variabel independent yaitu stres, aktivitas fisik, asupan lemak, asupan natrium dan variabel terikat yaitu hipertensi pada menopause yang berskala ordinal.

Selanjutnya dapat dilakukan analisis multivariat, yaitu untuk melihat hubungan antara satu variabel dependen dengan seluruh variabel independen, sehingga dapat diketahui variabel independen yang paling dominan berpengaruh terhadap hipertensi pada usia menopause dengan menggunakan uji Regressi Logistik Ganda. Uji Regressi Logistik Ganda dilakukan melalui beberapa tahapan untuk mendapatkan nilai $\mathrm{p}<$ 0,05 pada setiap variabel independen yang berhubungan dengan hipertensi pada usia menopause.

\section{HASIL}

Sejumlah 50 responden ibu-ibu menopause yang berada pada wilayah kerja Puskesmas Pangkalan Lada telah 
dipilih sebagai responden guna meneliti tentang hubungan asupan makanan, stres, dan aktivitas fisik terhadap peningkatan tekanan darah (hipertensi) pada usia menopause di wilayah kerja Puskesmas Pangkalan Lada.

\section{Analisis Univariat}

Gambaran Kejadian Hipertensi Pada Ibu-ibu Menopause di Puskesmas Pangkalan Lada.

Tabel 1.1 Distribusi Frekuensi

Berdasarkan Kejadian Hipertensi

\begin{tabular}{lll}
\hline Hipertensi & Jumlah & Persentase \\
\hline Pre Hipertensi & 15 & $30 \%$ \\
Hipertensi & 35 & $70 \%$ \\
\hline \multirow{2}{*}{ Jumlah } & 50 & 100 \\
\hline
\end{tabular}

Berdasarkan gambar 1.1 diketahui bahwa angka kejadian hipertensi untuk kategori prehipertensi yaitu berjumlah 15 responden (30\%) dan untuk kategori hipertensi sejumlah 35 responden $(70 \%)$.

\section{Gambaran Tingkat Stres Terhadap Peningkatan Tekanan Darah (Hipertensi) Pada Usia Menopause}

Tabel 1.2 Distribusi Frekuensi

Berdasarkan Tingkat Stres

\begin{tabular}{lll}
\hline Stres & Jumlah & Persentase \\
\hline Ringan & 15 & $30 \%$ \\
Sedang & 22 & $44 \%$ \\
Berat & 13 & $26 \%$ \\
\hline Jumlah & 50 & 100 \\
\hline
\end{tabular}

Berdasarkan gambar 1.2 diketahui bahwa sebagian besar responden memiliki tingkat stres sedang, yaitu sejumlah 22 responden (44\%), sedangkan untuk tingkat stres ringan sejumlah 15 responden (30\%), dan untuk tingkat stres berat sejumlah 13 responden $(26 \%)$.

\section{Gambaran Aktivitas Fisik Terhadap Peningkatan Tekanan Darah (Hipertensi) Pada Usia Menopause}

Tabel 1.3 Distribusi Frekuensi Berdasarkan Aktivitas Fisik

\begin{tabular}{lll}
\hline Akktivitas & & \\
Fisik & Jumlah & Persentase \\
\hline Ringan & 7 & $14 \%$ \\
Sedang & 29 & $58 \%$ \\
Berat & 14 & $28 \%$ \\
\hline Jumlah & 50 & 100 \\
\hline
\end{tabular}

Berdasarkan gambar 4.3 diketahui bahwa sebagian besar responden melakukan aktivitas fisik sedang, yaitu sejumlah 29 responden (58\%), sedangkan untuk aktivitas fisik ringan dilakukan sejumlah 7 responden (14\%), dan untuk aktivitas berat dilakukan sejumlah 14 responden (28\%).

\section{Gambaran Asupan Lemak Terhadap Peningkatan Tekanan Darah (Hipertensi) Pada Usia Menopause}

Tabel 1.4 Distribusi Frekuensi

Berdasarkan Asupan Lemak

\begin{tabular}{lll}
\hline $\begin{array}{l}\text { Asupan } \\
\text { Lemak }\end{array}$ & Jumlah & Persentase \\
\hline Rendah & 11 & $22 \%$ \\
Cukup & 18 & $36 \%$ \\
Lebih & 21 & $42 \%$ \\
\hline Jumlah & 50 & 100 \\
\hline
\end{tabular}

Berdasarkan gambar 1.4 diketahui bahwa asupan lemak responden seharihari sebagian besar dengan kategori asupan lemak lebih sejumlah 21 responden $(42 \%)$, sedangkan untuk kategori asupan lemak cukup sejumlah 18 responden (36\%), dan kategori asupan lemak rendahsejumlah 11 responden $(22 \%)$.

\section{Gambaran Asupan Natrium Terhadap Peningkatan Tekanan}


Darah (Hipertensi) Pada Usia Menopause

Tabel 1.5 Distribusi Frekuensi

Berdasarkan Asupan Natrium

\begin{tabular}{lll}
\hline Asupan & & \\
Natrium & Jumlah & Persentase \\
\hline Rendah & 9 & $18 \%$ \\
Cukup & 11 & $22 \%$ \\
Lebih & 30 & $60 \%$ \\
\hline Jumlah & 50 & 100 \\
\hline
\end{tabular}

Berdasarkan gambar 1.5 diketahui bahwa asupan natrium responden sehari-hari sebagian besar dengan kategori asupan natrium lebih sejumlah 30 responden $(60 \%)$, sedangkan untuk kategori asupan natrium cukup sejumlah 11 responden (22\%), dan kategori asupan natrium rendahsejumlah 9 responden $(18 \%)$.

\section{Analisis Bivariat}

\section{Hubungan Antara Tingkat Stres Dengan Hipertensi}

Tabel 1.6 Tabulasi silang Tingkat Stres dengan Hipertensi

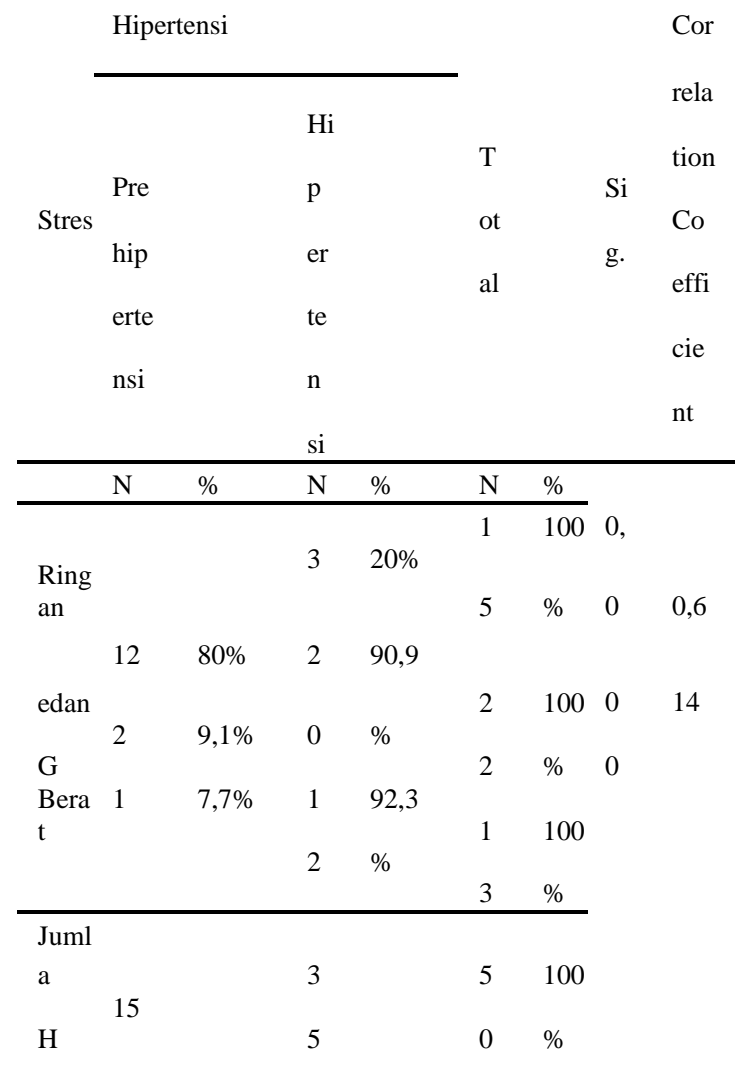

Berdasarkan tabel 1.6 tersebut menunjukan bahwa proporsi reponden untuk kategori stres ringandengan prehipertensi lebih banyak yaitu 12 responden (80\%), sedangkan untuk kategori stres ringan dengan hipertensi yaitu sebanyak 3 responden (20\%). Proporsi reponden yang untuk kategori stres sedang dengan hipertensi lebih banyak yaitu 20 responden $(90,9 \%)$ dibandingkan dengan proporsi responden untuk kategori stres sedang dengan prehipertensi yaitu 2 responden $(9,1 \%)$. Proporsi reponden untuk kategori stres berat dengan hipertensi lebih banyak yaitu 12 responden (92,3\%), dibandingkan dengan proporsi responden untuk kategori stres berat dengan prehipertensi yaitu 1 responden $(7,7 \%)$.

Berdasarkan tabel hasil uji korelasi spearman'rho diatas dapat diketahui bahwasannya koefisien korelasi adalah 0,614 dengan signifikansi 0,001 . Karena nilai signifikansinya $<0,05$ maka Ha diterima yang berarti terdapat hubungan yang signifikan antara hipertensi dengan tingkat stres .

\section{Hubungan Antara Aktivitas Fisik Dengan Hipertensi}

Tabel 1.7 Tabulasi silang Aktivitas Fisik dengan Hipertensi

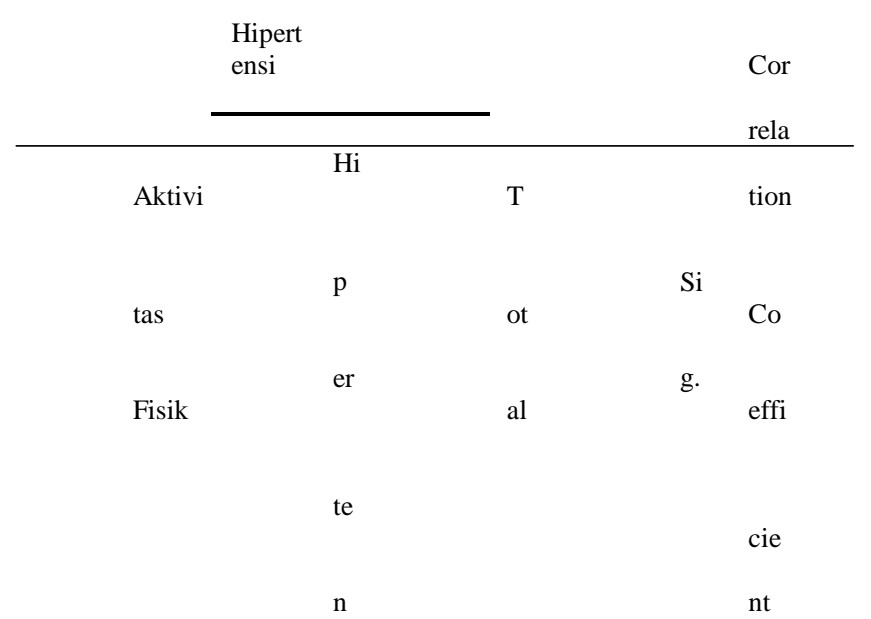




\begin{tabular}{|c|c|c|c|c|c|c|c|}
\hline & $\% \mathrm{~N}$ & & $\%$ & $\mathrm{~N}$ & $\%$ & & \multirow[b]{3}{*}{-} \\
\hline \multirow[b]{2}{*}{ Ring } & & & 100 & & 100 & 0 , & \\
\hline & $0 \%$ & & & 7 & & & \\
\hline an & 27 & 7 & $\%$ & 2 & $\%$ & 0 & 0,3 \\
\hline \multirow[t]{2}{*}{ Seda } & $6 \%$ & 2 & 72 & 9 & 100 & 1 & \\
\hline & 50 & 1 & $4 \%$ & 1 & $\%$ & 7 & \\
\hline \multirow[b]{2}{*}{ Berat } & & 7 & 50 & \multirow{2}{*}{4} & 100 & & \\
\hline & $\%$ & & & & & & \\
\hline Juml & & 3 & & 5 & 100 & & \\
\hline ah & & 5 & & 0 & $\%$ & & \\
\hline
\end{tabular}

Berdasarkan tabel 1.7 tersebut menunjukan bahwa proporsi reponden untuk kategori aktivitas fisik ringandengan hipertensi yaitu sebanyak 7 responden (100\%). Proporsi reponden yang untuk kategori aktivitas fisik sedang dengan hipertensi lebih banyak yaitu 21 responden $(72,4 \%)$ dibandingkan dengan proporsi responden untuk kategori aktivitas fisik sedang dengan prehipertensi yaitu 8 responden (27,6\%).Proporsi reponden untuk kategori aktivitas fisik berat dengan prehipertensi yaitu 7 responden (50\%), sebanding dengan proporsi responden untuk kategori aktivitas fisik berat dengan hipertensi yaitu 7 responden $(50 \%)$.

Berdasarkan tabel hasil uji korelasi spearman's rho diatas dapat diketahui bahwasannya koefisien korelasi adalah $-0,335$ dengan signifikansi 0,017 . Karena nilai signifikansinya $<0,05$ maka $\mathrm{Ha}$ diterima yang berarti terdapat hubungan yang signifikan antara hipertensi dengan aktivitas fisik .

\section{Hubungan Antara Asupan Lemak Dengan Hipertensi}

Tabel 1.8 Tabulasi silang Asupan Lemak dengan Hipertensi

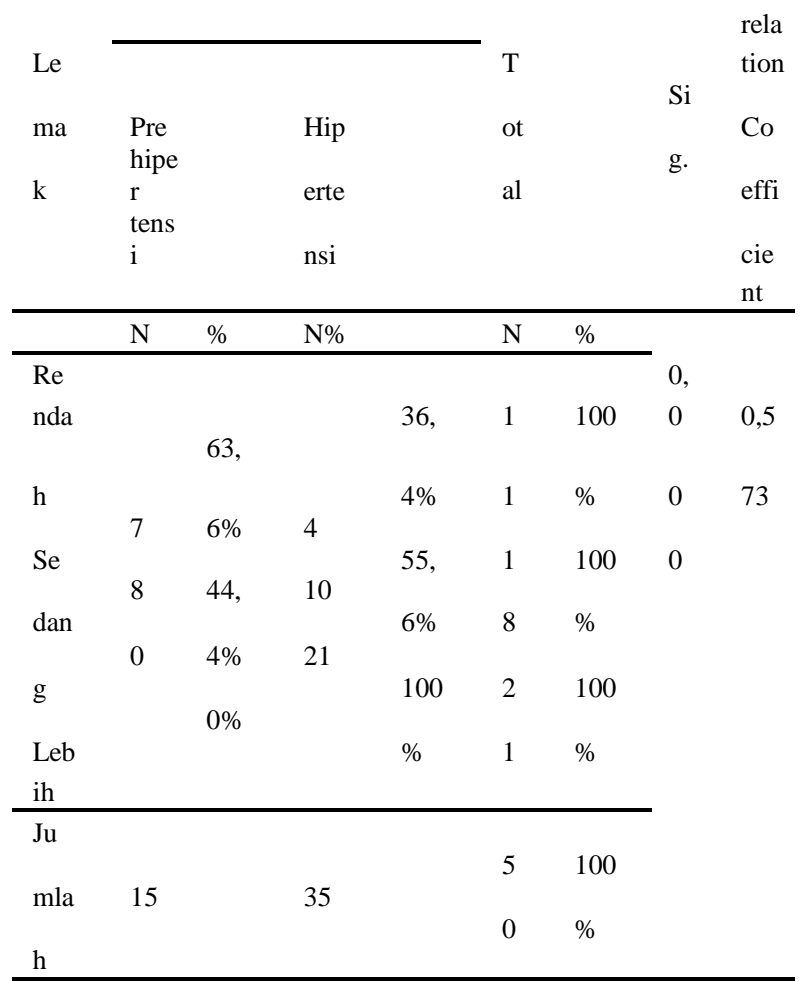

$\mathrm{h}$ 
Berdasarkan tabel 1.8 tersebut menunjukan bahwa proporsi reponden untuk kategori asupan lemak rendah dengan prehipertensi lebih banyak yaitu 7 responden $(63,6 \%)$, sedangkan untuk kategori asupan lemak rendah dengan hipertensi yaitu sebanyak 4 responden $(36,4 \%)$. Proporsi reponden yang untuk kategori asupan lemak sedang dengan hipertensi lebih banyak yaitu 10 responden $(55,6 \%)$ dibandingkan dengan proporsi responden untuk kategori asupan lemak sedang dengan prehipertensi yaitu 8 responden $(44,4 \%)$. Proporsi reponden untuk kategori asupan lemak lebih dengan hipertensi lebih banyak yaitu 21 responden $(100 \%)$.

Berdasarkan tabel hasil uji korelasi spearman's rho diatas dapat diketahui bahwasannya koefisien korelasi adalah 0,573 dengan signifikansi 0,001 . Karena nilai signifikansinya $<0,05$ maka Ha diterima yang berarti terdapat hubungan yang signifikan antara hipertensi dengan asupan lemak .

\section{Hubungan Antara Asupan Natrium Dengan Hipertensi}

Tabel 1.9 Tabulasi silang Asupan Natrium dengan Hipertensi

Cor

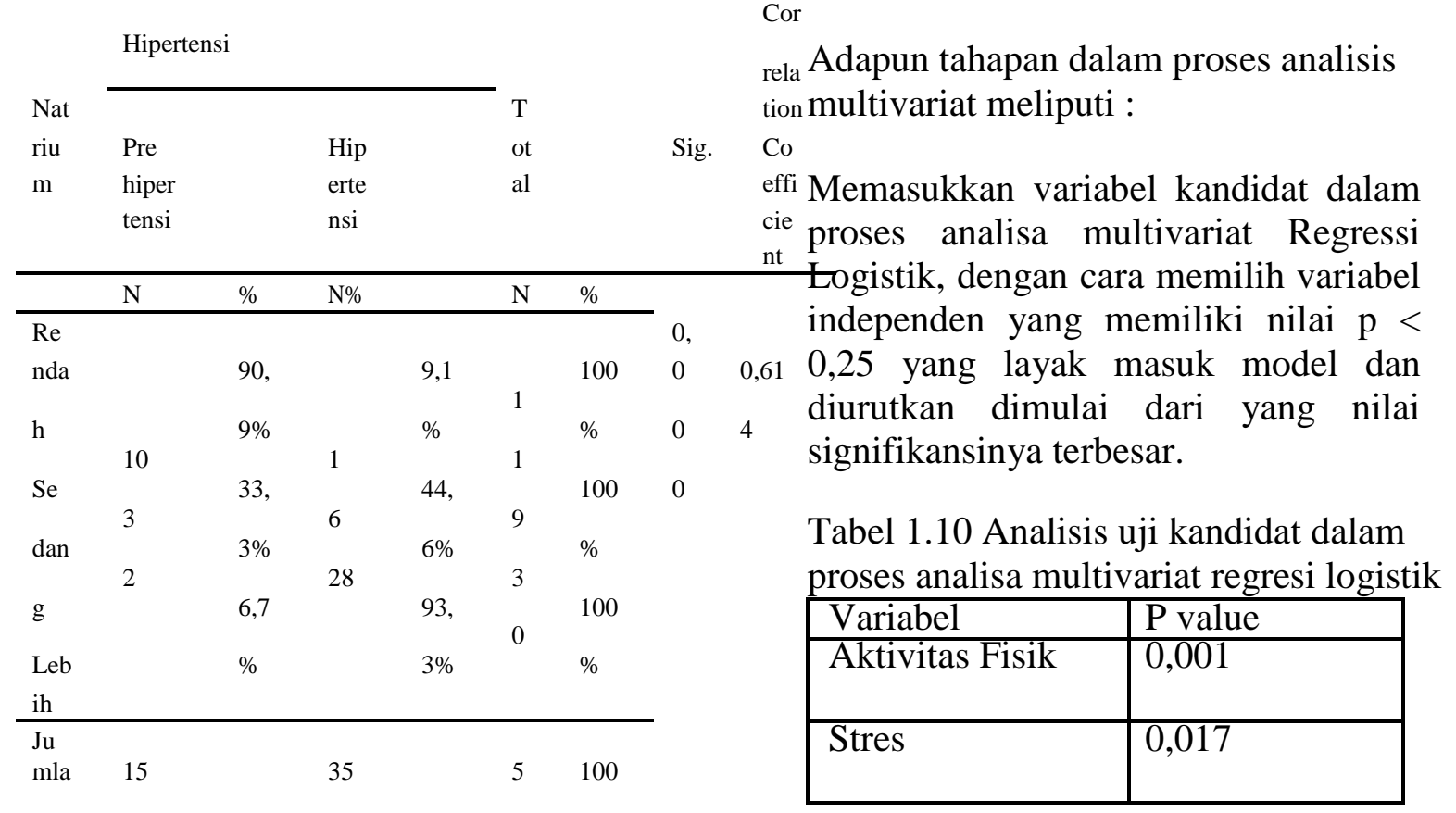

Berdasarkan tabel 1.9 tersebut menunjukan bahwa proporsi reponden untuk kategori asupan natrium rendah dengan prehipertensi lebih banyak yaitu 10 responden $(90,9 \%)$, sedangkan untuk kategori asupan lemak rendah dengan hipertensi yaitu sebanyak 1 responden $(9,1 \%)$. Proporsi reponden untuk kategori asupan natrium sedang dengan hipertensi lebih banyak yaitu 6 responden $(44,6 \%)$ dibandingkan dengan proporsi responden untuk kategori asupan natrium sedang dengan prehipertensi yaitu 2 responden $(6,7 \%)$. Proporsi reponden untuk kategori asupan antrium lebih dengan hipertensi lebih banyak yaitu 28 responden (93,3\%), dibandingkan dengan proporsi responden untuk kategori asupan natrium lebih dengan prehipertensi yaitu 1 responden $(6,7 \%)$. Berdasarkan tabel hasil uji korelasi spearman's rho diatas dapat diketahui bahwasannya koefisien korelasi adalah 0,702 dengan signifikansi 0,001 . Karena nilai signifikansinya $<0,05$ maka Ha diterima yang berarti terdapat hubungan yang signifikan antara hipertensi dengan asupan natrium.

\section{Analisis Multivariat}

rela Adapun tahapan dalam proses analisis

Co

cie proses analisa multivariat Regressi togistik, dengan cara memilih variabel independen yang memiliki nilai $\mathrm{p}<$ diurutkan dimulai dari yang nilai signifikansinya terbesar.

Tabel 1.10 Analisis uji kandidat dalam proses analisa multivariat regresi logistik 
\begin{tabular}{|l|l|} 
Asupan Lemak & 0,001 \\
\hline Asupan Natrium & 0,001 \\
\hline
\end{tabular}

Hasil analisis uji kandidat semua variabel independen memiliki $\mathrm{p}<$ 0,25 sehingga terpilih untuk masuk ke dalam uji selanjutnya, bererti ada 4 variabel yang akan di uji yaitu: aktivitas fisik, stres, asupan lemak, dan asupan natrium. Langkah berikutnya adalah memasukkan keempat variabel diatas dalam regresi logistik ganda.

Tabel 1.11 Hasil analisis Multivariat variabel stres, aktivitas fisik, asupan lemak, dan asupan natrium terhadap hipertensi pada menopause.

\begin{tabular}{lll}
\hline Variabel & Exp (B) & p-value \\
& & \\
\hline $\begin{array}{l}\text { Asupan } \\
\text { Lemak }\end{array}$ & 2,205 & 0,416 \\
Aktivitas & 0,029 & 0,108 \\
Fisik & & \\
Stres & 31,949 & 0,069 \\
Asupan & 15,404 & 0,021 \\
Natrium & & \\
\hline
\end{tabular}

Tabel analisis 1.11 multivariat logistik menunjukkan bahwa variabel asupan lemak, aktivitas fisik dan stres memiliki $\mathrm{p}$ value > 0,05 , sehingga harus dikeluarkan dari model. Variabel asupan natrium memiliki nilai $\mathrm{p} 0,021$ $<0,05$, dengan nilai OR: 15,40 . Sehingga ada hubungan yang signifikan antara asupan natrium dengan hipertensi pada usia menopause , kadar asupan natrium yang lebih akan meningkatkan 15,39 kali lebih tinggi daripada natrium rendah.

Sedangkan untuk variabel stres dengan nilai $\mathrm{p}$ 0,069 OR:31,94, dapat diartikan bahwa stres meningkatkan risiko terjadinya hipertensi 31,94 daripada yang tidak stres. Namun secara statistik tidak signifikan karena nilai $\mathrm{p}>0,05$.

\section{PEMBAHASAN}

\section{Tingkat Stres}

\section{Analisis Deskriptif Tentang Tingkat Stres}

Melihat hasil yang didapatkan dari penelitian mengenai tingkat stress pada wanita menopause sebagian besar berada pada kategori sedang. Berdasarkan indikator stres yang berasal dari dalam diri (kesehatan fisik \& psikologis) adapun sebagian besar hal yang dialami responden merasakan gejolak panas pada malam hari yang dapat menyebabkan gangguan pola istirahat sehingga responden mengalami susah untuk beristirahat, dan merasa mudah marah ataupun mudah tersinggung. Sedangkan untuk indikator stres yang berasal dari luar (psikosial), yaitu stres yang dapat berasal dari keluarga dan lingkungan masyarakat. Antara lain sebagian responden merasa takut membebani tinggal dengan keluarga besarnya (menantu) sehingga dapat menjadi beban fikiran, beban fikiran yang terus menerus terpendam dapat menimbulkan stres pada individu.

Pengertian stres dalam kamus psikologi Chaplin (2000), stres merupakan keadaan tertekan, baik secara fisik maupun psikologis. Keadaan yang membuat tertekan ini karena adanya kebutuhan dan dorongan yang tidak sesuai dengan kenyataan yang diharapkan, serta respon masingmasing individu yang berbeda. Artinya stressor (sesuatu yang dapat membuat stres/pemicu stres) yang sama bisa 
ditanggapi secara berbeda oleh dua atau lebih individu yang berbeda. Jelas itu berkaitan dengan persepsi, tanggapan (response), dari masingmasing individu.

Tahapan sebelum seseorang mengalami stres, ia akan mengalami frustasi terlebih dahulu karena sesuatu yang menghambat tercapainya tujuan hidup itulah yang dinamakan frustasi. Frustasi yang terus menerus dan orang yang bersangkutan tidak mampu mengatasinya maka keadaan tersebut dinamakan stres (Chaplin (2000).

Stres sebagai kondisi yang disebabkan oleh transaksi antara individu dengan lingkungan dari situasi yang ada dengan sumber-sumber dengan sistem biologis, psikologis, dan dari individu (Smeth, 2004).

\section{Analisis Korelasi Antara Tingkat Stres Dengan Hipertensi Pada Usia Menopause}

Hipotesis dalam penelitian ini menyatakan bahwa "Ada hubungan antara stress dengan hipertensi". Berdasarkan analisis data yang dilakukan, hipotesis ini dinyatakan diterima dengan korelasi antara stres dengan hipertensi. Hal ini menunjukkan bahwa semakin tinggi tingkat stres, maka semakin tinggi resiko terjadinya hipertensi pada menopause.

Adanya hubungan tersebut dapat dijelaskan bahwa stres pada wanita menopause dikarenakan stresor yang berasal dari dalam (fisik dan psikis) maupun dari luar (psikososial) yang terjadi secara berkelanjutan. Frustasi yang terus menerus dan orang yang bersangkutan tidak mampu mengatasinya maka keadaan tersebut dinamakan stres (Chaplin, 2000).
Sumber stres di dalam diri seseorang salah satunya melalui kesakitan. Menderita sakit, memberi tuntutan pada sistem biologis dan psikologis individu. Tingkat stres yang ditimbulkan oleh tuntutan itu tergantung pada keseriusan penyakit serta umur individu. Pada usia menopause hal ini bisa muncul akibat perubahan hormonal yang dapat mengganggu pola tidur, merasa kurang percaya diri terhadap perubahan fisiologis yang terjadi (Manuaba, 2009).

Hubungan antara stres dengan hipertensi karena terjadinya peningkatan aktivitas saraf simpatis mengakibatkan meningkatkan tekanan darah secara tidak menentu. Hipotalamus menerima masukan mengenai stresor fisik dan emosi dari hampir semua dareah di otak dan dari banyak reseptor di seluruh tubuh. Sebagai respons saraf utama terhadap rangsangan stres adalah pengaktifan menyeluruh saraf simpatis. Hal itu menyebabkan peningkatan curah jantung dan ventilasi serta pengalihan darah dari daerah-daerah vasokonstriksi yang aktivitasnya ditekan sehingga menyebabkan kenaikan tekanan darah (Hawari, 2001).

Hal ini sejalan dengan hasil dari penelitian Andria (2013) pada kelompok lansia diperoleh hasil stres mempunyai hubungan bermakna dengan terjadinya hipertensi pada lansia, diperoleh $\mathrm{p}=0,000(\mathrm{p}<0,05)$. Sebagian besar responden kurang kebal terhadap stress yaitu sebesar $63,55 \%$ dan sebagian kecil responden kebal terhadap stress yaitu sebesar 36,44\%. Hal ini disebabkan karena beberapa 
faktor salah satunya adalah sulit untuk tidur.

Hasil dari penelitian Fitriani (2012) diperoleh hasil bahwa kejadian hipertensi berhubungan bermakna dengan keadaan stres nilai $\mathrm{p}<0,05)$. Tekanan darah tidak hanya dipengaruhi oleh faktor fisik tetapi juga oleh emosi, sehingga seseorang dapat dianggap menderita hipertensi saat diperiksa disebabkan faktor emosi.

Berdasarkan penelitian tentang hubungan antara kenaikan tekanan darah dan tanggapan fibrinogen plasma terhadap stres dengan kejadian hipertensi. Diperoleh hasil pada wanita, respon stres secara independen memprediksi resiko hipertensi, dengan $\mathrm{p}=0,045<0,05$. Data ini menunjukkan bahwa tinggi reaktivitas kardiovaskular dan peradangan stres mental dikaitkan dengan risiko hipertensi, dan mungkin mekanisme melalui faktor psikososial berdampak pada perkembangan hipertensi (Steptoe, Kivimäki, Lowe, Rumley, \& Hamer, 2016).Pada wanita usia lanjut, khususnya menopause faktor psikososial yang dapat mempengaruhi stres antara lain, kehilangan anggota keluarga / kehilangan pasangan hidup, merasa sendiri, merasa tidak berguna lagi, merasa kurang diperhatikan, hubungan yang penuh konflik dapat memainkan peran yang negatif yang lebih besar. Sebuah survei longitudinal pada 515 usia lanjut menemukan bahwa hubungan yang sulit dan tidak menyenangkan ditambah dengan kritik, penolakan, kompetisi, pelanggaran privasi, dan kurangnya timbal balik dapat menjadi penyebab stres yang kronis (Krause \& Rook dalam Papalia, 2015).

Dalam sebuah penelitian selama 10 tahun dari penduduk di Finlandia., perempuan yang menerima dukungan yang paling khusus, seperti perasaan dibutuhkan dan dihargai, rasa memiliki, dan keintiman emosional 2,5 kali lebih kecil kemungkinan untuk meninggal dalam periode penelitian dibandingkan dengan mereka yang tidak menerima dukungan tersebut (Papalia, 2015).

Stres memang tidak menyebabkan hipertensi yang menetap namun jika episode stress sering terjadi dapat menyebabkan kenaikan sementara yang sangat tinggi. Pentingnya hubungan sosial pada masa ini karena, dukungan emosional dapat membantu lansia dalam mempertahankan kepuasan hidup ketika menghadapi stres dan trauma.

Aktivitas Fisik

Analisis Deskriptif Tentang Aktivitas Fisik

Melihat hasil yang didapatkan dari penelitian mengenai aktivitas fisik pada wanita menopause sebagian besar berada pada kategori sedang. Berdasarkan indikator aktivitas fisikyang dilakukan responden seharihari meliputi pekerjaan, berolahraga, dan kegiatan pada waktu luang.

Sebagian besar responden dengan kategori aktivitas fisik sedang dengan indikator aktivitas pekerjaan yang dilakukan responden sehari-hari meliputi pekerjaan ibu rumah tangga yang termasuk dalam kategori sedang misalnnya, masak, mencuci, menyapu, mengepel, dll. Sedangkan untuk indikator aktivitas olahraga sebagian besar responden berolahraga ketika mengikuti kegiatan senam lansia yang diadakan setiap satu minggu sekali oleh kader-kader binaan posyandu lansia. Hanya beberapa responden yang sering melakukan jalan-jalan santai ketika pagi hari minimal 30 menit. 
Pada waktu luang beberapa responden memanfaatkan untuk menonton tv ataupun istirahat dan menyelesaikan pekerjaan yang lainnya. Untuk responden yang melakukan aktivitas fisik ringan rata-rata mereka hanya melakukan kegiatan sehari-hari sebagai ibu rumah tangga dan jarang melakukan aktivitas-aktivitas yang berat ataupun olahraga dengan alasan ketika ada kegiatan olahraga/senam untuk lansia mereka sedang beralasan untuk tidak bisa mengikuti secara rutin.

Untuk aktivitas fisik berat responden bekerja sebagai ibu rumah tangga dan wiraswasta atau berkebun. Rata-rata responden yang melakukan aktivitas berat masih memiliki fisik yang kuat sehingga mereka selalu terbiasa aktif untuk bekerja. Sebelum melakukan aktivitas bekerja rata-rata responden melakukan pekerjaan rumah tangga secara rutin sehingga tubuh memiliki kesempatan yang cukup untuk membakar lemak. Beberapa responden juga rajin memanfaatkan waktu luang pagi hari sebelum beraktivitas untuk berolahraga 2-3x seminggu.

Aktivitas fisik memerlukan usaha ringan, sedang atau berat yang dapat menyebabkan perbaikan kesehatan bila dilakukan secara teratur. Setiap kegiatan aktivitas fisik yang dilakukan membutuhkan energy yang berbeda tergantung dari lamanya intesitas dan kerja otot. Tidak adanya aktivitas fisik (kurang aktivitas fisik) merupakan faktor resiko berbagai penyakit kronis dan secara keseluruhan diperkirakan menyebabkan kematian secara global (WHO, 2001).

Aktivitas fisik disebut juga aktivitas eksternal, yaitu sesuatu yang menggunakan tenaga atau energi untuk melakukan berbagai kegiatan fisik, seperti berjalan, berlari, dan berolahraga . Setiap kegiatan fisik membutuhkan energi yang berbeda menurut lamanya intensitas dan sifat kerja otot. Latihan fisik dapat meningkatkan kemampuan fungsional dan menurunkan kebutuhan oksigen otot jantung yang diperlukan pada setiap penurunan aktivitas fisik seseorang. Aktivitas fisik adalah gerakan yang dilakukan oleh otot tubuh dan sistem penunjangnya (Wilmore et al, 2004).

\section{Analisis Diskriptif Korelasi Tentang Aktivitas Fisik Terhadap Hipertensi Pada Usia Menopause}

Hipotesis dalam penelitian ini menyatakan bahwa "Ada hubungan antara aktivitas fisik dengan hipertensi". Berdasarkan analisis data yang dilakukan, hipotesis ini dinyatakan diterima dengan korelasi antara aktivitas fisik dengan hipertensi sebesar 0,017. Hal ini menunjukkan bahwa semakin rendah aktivitas fisik yang dilakukan, maka semakin tinggi resiko terjadinya hipertensi pada menopause.

Adanya hubungan tersebut dapat dijelaskan bahwa aktivitas fisik pada wanita menopause dikarenakan sebagian besar responden beekerja sebagai ibu rumah tangga, sehingga intensitas aktivitas fisik yang dilakukan antara lain: memasak, mengepel, mencuci, duduk, ataupun pekerjaan rumah lainnya yang termasuk kedalam kategori aktivitas fisik sedang dan ringan

Kurangnnya aktivitas fisik merupakan faktor resiko terjadinya berbagai penyakit kronis dan secara keseluruhan diperkirakan menyebabkan kematian secara global (WHO, 2001). Memulai program olahraga dan kegiatan fisik lainnya dapat membuat perasaan menjadi lebih baik, memiliki banyak 
energi, mengurangi berat badan, menurunkan kadar kolesterol, menurunkan tekanan darah, memperbaiki penampilan. Selain itu juga olahraga olahraga rutin dan kegiatan aktivitas fisk lainnya dapat meningkatkan HDL kolesterol terutama jika olahraga dikaitkan dengan penurunan berat badan (obesitas) (Douglas, 2001).

Bagi penderita hipertensi harus rutin untuk menjaga kesehatan tubuh dengan berolahraga agar lemak yang ada didalam tubuh tidak tertimbun di dalam darah yang dapat menjadi kolestrol sehingga menghambat penyaluran oksigen kedalam otak. Hal ini dapat dijelaskan bahwa aktivitas fisik yang kurang akan meningkatkan resiko kegemukan yang juga merupakan salah satu faktor resiko dari hipertensi dan penyakit degeneratif lainnya. Aktivitas fisik seperti olahraga yang teratur akan menurunkan tahanan perifer untuk menurunkan tekanan darah. Selain itu, olehraga yang teratur melatih otot jantung dalam pekerjaan berat di kondisi tertentu, sehingga otot jantung memompa darah lebih keras dan sering. Hal ini akan menyebabkan tekanan pada dinding arteri semakin besar (Price \& Wilson, 2006).

Berdasarkan salah satu penelitian di India menemukan ada hubungan yang signifikan secara statistik antara hipertensi dan aktivitas fisik pada waktu luang $(\mathrm{P}=0,009)$. Rasio Odds ditemukan menjadi 2,51 menunjukkan tidak adanya aktivitas fisik waktu luang meyebabkan dua kali risiko terhadap hipertensi bila dibandingkan dengan aktivitas fisik waktu luang yang positif. Beberapa peneliti telah membuktikan bahwa jangka panjang latihan aerobik memiliki efek menguntungkan pada darah sistolik tekanan (Wang, Tiwari, \& Wang, 2014).

Memanfaatkan waktu luang sebagai kegiatan untuk melakukan latihan aerobik sebagai pengurangan faktor risiko penyakit kardiovaskular pada wanita pascamenopause dengan hipertensi dan obesitas. Latihan aerobik dapat menurunan BMI dan tekanan darah secara bersama-sama dengan meningkatkan endotel tingkat NO (nitrogen monoxide), yang memainkan peran penting untuk melindungi terhadap hipertensi pascamenopause (Turky, Elnahas, \& Oruch, 2013).

Petter (2016) menambahkan peningkatan aktivitas fisik harus menjadi komponen penting dari setiap pencegahan hipertensi dan harus dipromosikan oleh tenaga kesehatan. Secara umum, hasil penelitiannya menunjukkan bahwa program pelatihan latihan aerobik terstruktur intensitas sedang atau peningkatan aktivitas fisik volume yang memadai dan hasilnya intensitas dalam pengurangan sekitar 4$10 \mathrm{mmHg}$ tekanan darah sistolik dan 3$8 \mathrm{mmHg}$ tekanan darah diastolik pada pasien dengan hipertensi tahap 1 .

Wanita menopause memiliki penurunan daya tahan tubuh yang bersifat fisiologis, sehingga perlunya tubuh yang aktif untuk membantu proses metabolisme tubuh pada wanita usia menopause dapat meminimalisir terjadinya peningkatan tekanan darah (hipertensi). Menopause tentu bukan satu-satunya faktor yang mempengaruhi munculnya penyakit kardiovaskuler atau hipertensi pada wanita. Faktor gaya hidup, medis, dan genetik juga sangat berperan dalam insidensi penyakit kardiovaskuler pada wanita (Andrews, 2009). 


\section{Asupan Lemak}

\section{Analisis Diskriptif Tentang Asupan Lemak}

Melihat hasil yang didapatkan dari penelitian mengenai asupan lemak pada wanita menopause sebagian besar berada pada kategori asupan lemak lebih. Sebagian besar responden dengan asupan lemak lebih dengan mengkonsumsi makanan yang bersantan dengan intensitas 2-3x perminggu dan penggunaan makanan dengan minyak dan margarine untuk menggoreng lauk memasak sayuran tumis. Konsumsi bahan makanan yang tinggi kadar lemaknya misalnya makanan yang siap saji (sarden) yang mengandung lemak dan bakso $1 \mathrm{x}$ dalam minggu. Dari hasil pengisian Food Frequency Questionry (FFQ) semi kuantitatif diperoleh hasil untuk asupan lemak lebih pada sebagian responden dengan penghitungan terhadap komposisi lemak dalam bahan makanan rata-rata perhari dengan hasil $>$ 20-30\% dari anjuran asupan lemak perhari atau sebesar 44,4-66,7mg.

WHO menganjurkan konsumsi lemak sebanyak 20-30 \% dari kebutuhan energi total dianggap baik untuk kesehatan. Jumlah ini memenuhi kebutuhan akan asam lemak esensial dan untuk membantu penyerapan vitamin larut-lemak.Sumber utama lemak adalah minyak tumbuhtumbuhan (minyak kelapa, kelapa sawit, kacang tanah, kacang kedelai, jagung, dsb), mentega, margarin, dan lemak hewan (lemak daging dan ayam). Sumber lemak lain adalah kacang-kacangan, biji-bijian, daging, ayam, krim, susu, keju dan kuning telur, serta makanan yang dimasak dengan lemak atau minyak (Almatsier, 2009).
Sedangkan untuk responden dengan kategori asupan lemak cukup dan asupan lemak kurang dengan penghitungan terhadap komposisi lemak dalam bahan makanan rata-rata perhari dengan hasil $\leq 20-30 \%$ dari kebutuhan energi total perhari. Sebagian responden dengan asupan lemak cukup dan kurang rata-rata mereka lebih banyak mengkonsumsi sayur dan buah, dengan sebagian besar konsumsi lauk nabati (tahu,tempe) dan pengolahan jarang di tumis atau menggunakan minyak, misalnya sayur bening, sayur sop, ataupun sayursayuran yang direbus, penggunaan santan pun diminimalisir hanya berkisar 2-3x dalam perbulan, atau bahkan sangat jarang mengkonsumsi makanan yang bersantan.

Konsumsi diet tinggi buah dan sayur dan diet rendah lemak dengan cara mengurangi asupan lemak jenuh dan lemak total. Kalium dapat menurunkan tekanan darah dengan meningkatkan jumlah natrium yang terbuang bersama air kencing. Dengan setidaknya mengkonsumsi buah-buahan sebanyak 3-5 kali sehari, seorang bisa mencapai asupan potassium yang cukup (Soeparman, 2001).

\section{Analisis Diskriptif Korelasi Antara Asupan Lemak dengan Hipertensi Pada Usia Menopause}

Hipotesis dalam penelitian ini menyatakan bahwa "Ada hubungan antara asupan lemak dengan hipertensi". Berdasarkan analisis data yang dilakukan, hipotesis ini dinyatakan diterima dengan korelasi antara asupan lemak dengan hipertensi. Hal ini menunjukkan bahwa semakin tinggi asupan lemak yang dikonsumsi, maka semakin tinggi resiko terjadinya hipertensi pada menopause. 
Hubungan antara asupan lemak dengan hipertensi, jika dilihat dari hasil kuesioner dan wawancara dapat diketahui bahwa sebagian besar responden termasuk kedalam kategori asupan lemak lebih. Rata-rata responden mengkonsumsi lemak lebih dari $20-30 \%$ atau setara dengan $44,4-$ $66,7 \mathrm{mg}$ perhari. Dapat diketahui bahwa lemak yang berlebihan didalam tubuh dapat meningkatkan kadar kolesterol dalam darah sehingga menimbulkan terjadinya hipertensi.

Hal ini sependapat dengan penelitian dari Lidyawati (2014) berdasarkan hasil analisis bivariat menunjukkan asupan asam lemak jenuh memiliki hubungan yang bermakna dan merupakan faktor risiko hipertensi pada wanita menopause $(\mathrm{P}=0,02$, $\mathrm{OR}=5,76$, CI $95 \%=1,141-29,078)$, sedangkan asupan asam lemak tidak jenuh MUFA, PUFA dan natrium tidak berhubungan dengan kejadian hipertensi karena nilai $\mathrm{P}>0,05$.

Kolesterol didalam tubuh terutama diperoleh dari hasil sitesis di dalam hati. Jumlah yang disintesis bergantung pada kebutuhan tubuh dan jumlah yang diperoleh dari makanan. Kolesterol hanya terdapat di dalam makanan asal hewan (asam lemak jenuh). Sumber utama kolesterol adalah, hati, ginjal, dan kuning telur. Setelah itu daging, susu, keju, udang, dan kerang. Ikan dan daging ayam sedikit mengandung kolesterol. Oleh karena itu, dianjurkan di dalam diet rendah kolesterol (Almatsier, 2009).

Kolesterol memberikan indikasi tentang jantung dan penyakit arteri pada umumnya. Beberapa studi menunjukkan korelasi yang baik dari kolesterol yang tinggi dengan hipertensi. Kolesterol hanya ditemukan dalam produk hewan seperti lemak jenuh hewani dari daging merah, unggas, telur, dan produk susu. Konsumsi produk makanan ini harus dibatasi untuk mengendalikan kolesterol. Lemak dan minyak harus dikurangi dalam diet, dan itu juga harus berasal dari sumber nabati. Tidak ada "lemak baik" (selain omega-3 suplemen), semua trans-lemak, maupun lemak dan minyak terhidrogenasi harus benar-benar dihindari. Untuk hidup lebih lama dianjurkan untuk mengkonsumsi kalori yang lebih rendah dengan memilih bijibijian, kacang-kacangan, sayuran, dan buah-buahan (Sharma, 2015).

Konsumsi diet tinggi buah dan sayur dan diet rendah lemak dengan cara mengurangi asupan lemak jenuh dan lemak total. Kalium dapat menurunkan tekanan darah dengan meningkatkan jumlah natrium yang terbuang bersama air kencing. Dengan setidaknya mengkonsumsi buah-buahan sebanyak 3-5 kali sehari, seorang bisa mencapai asupan potassium yang cukup (Soeparman, 2001).

\section{Asupan Natrium}

\section{Analisis Deskriptif Tentang Asupan Natrium}

Melihat hasil yang didapatkan dari penelitian mengenai asupan natrium pada wanita menopause sebagian besar berada pada kategori asupan natrium lebih. Asupan natrium diperoleh berdasarkan pengisian Food Frequency Questionry (FFQ) semi kuantitatif yang terdiri dari bahan makanan yang dikonsumsi sehari-hari yang disesuaikan dengan daftar komposisi bahan makanan (DKBM).

Dari hasil pengisian Food Frequency Questionry (FFQ) semi kuantitatif 
asupan natrium yang di konsumsi responden sebagian besar berasal dari lauk pauk misalnya, ikan asin, ikan teri, telur, dan tanpa disadari penggunaan bahan penyedap dan garam dapur yang tidak terkontrol. Dalam memasak untuk $3 \mathrm{x}$ sehari penggunaan garam minimal 1 sendok teh atau setara dengan $2000 \mathrm{mg}$ perhari. Bagi penderita hipertensi hal ini harus sangat diperhatikan apalagi masih adanya penggunaan msg atau bumbu penyedap yang sangat besar kandungan natriumnya. Tanpa disadari penggunaan kecap juga beresiko meningkatkan penggunaan natrium yang lebih. Asupan natrium lebih dengan penghitungan terhadap komposisi lemak dalam bahan makanan rata-rata perhari dengan hasil $>2000 \mathrm{mg}$ asupan natrium perhari.

Natrium adalah kation utama dalam cairan ekstraseluler tubuh yangmempunyai fungsimenjaga keseimbangan cairan dan asam basa tubuh,serta berperan dalam transmisi syaraf dan kontraksi otot. ( Almatiser, 2009).

Konsumsi garam yang dianjurkan dalam Permenkes RI (2014) untuk penggunaan natrium $2000 \mathrm{mg}$ perhari atau setara dengan 1 sendok teh garam.

Untuk kategori asupan natrium cukup dan asupan natrium rendah rata-rata responden mengkonsumsi garam s 2000mg perhari atau setara dengan 1sendok teh perhari dan meminimalisir penggunaan msg atau bahkan tidak menggunakannya. Responden yang mengerti diet yang dilakukan untuk penderita hipertensi sangat meminimalisir hal-hal yang dapat dengan mudah memicu hipertensi.

\section{Analisis Diskriptif Korelasi Tentang Asupan Natrium Terhadap Hipertensi Pada Usia Menopause}

Hipotesis dalam penelitian ini menyatakan bahwa "Ada hubungan antara asupan natrium dengan hipertensi". Berdasarkan analisis data yang dilakukan, hipotesis ini dinyatakan diterima dengan korelasi antara asupan natrium dengan hipertensi sebesar 0,001. Hal ini menunjukkan bahwa semakin tinggi asupan natrium yang dikonsumsi, maka semakin tinggi resiko terjadinya hipertensi pada menopause.

Hubungan antara asupan natrium dengan hipertensi, jika dilihat dari hasil penghitungan FFQ dapat diketahui bahwa sebagian besar responden termasuk kedalam kategori asupan natrium lebih diperoleh hasil untuk asupan natrium lebih terhadap komposisi natrium dalam bahan makanan rata-rata perhari dengan hasil $>2000 \mathrm{mg}$ asupan natrium perhari. Peningkatan asupan garam dapat mempengaruhi peningkatan tekanan darah, terutama pada wanita menopause dengan penurunan fungsi tubuh dapat mempermudah penumpukan cairan tubuh. Hal ini sependapat dengan teori Kaplan (2006).

Garam menyebabkan penumpukan cairan dalam tubuh, karena menarik cairan diluar sel agar tidak keluar, sehingga akan meningkatkan volume dan tekanan darah. Pada manusia yang mengkonsumsi garam 3 gram atau kurang ditemukan tekanan darah ratarata rendah, sedangkan asupan garam sekitar 7-8 gram tekanan darahnya rata-rata lebih tinggi (Kaplan, 2006).

Hal ini sejalan dengan penelitian Lestari (2010) dengan judul Hubungan Asupan Kalium, Kalsium, Magnesium, 
dan Natrium, Indeks Massa Tubuh, serta Aktifitas Fisik dengan Kejadian Hipertensi pada Wanita Usia $30-40$ Tahun, diperoleh hasil penelitian menunjukkan adanya hubungan antara asupan natrium $(\mathrm{p}=0,000, \mathrm{RP}=44,0$; $95 \% \mathrm{CI}=4,62,418,92)$ dan aktifitas fisik $(\mathrm{p}=0,042)$ dengan kejadian hipertensi.

Hasil dari penelitian (Muliyati, Syam, \& Sirajuddin, 2010) pada lansia diperoleh hasil penelitian menunjukkan bahwa natrium pola diet memiliki korelasi yang signifikan $(\mathrm{P}=0,000)$. Responden yang mengkonsumsi natrium lebih $(93,7 \%)$ menderita hipertensi lebih banyak dibandingkan yang kurang mengkonsumsi natrium.

Hal tersebut sesuai dengan pendapat Soeparman (2001) bahwa garam merupakan hal yang sangat sentral dalam patofisiologi hipertensi. Hipertensi hampir tidak pernah ditemukan pada golongan suku bangsa dengan asupan garam minimal. Apabila asupan garam kurang dari 3 gram perhari, prevalensi hipertensi beberapa persen saja, sedangkan apabila asupan garam 5-15 gram perhari, prevalensi hipertensi meningkat menjadi $15-20 \%$.

Berdasarkan hasil dari penelitian (Kim, Kim, Lee, Lee, \& Wang, 2014)dengan judul Postmenopausal hypertension and sodium sensitivity, menjelaskan bahwa mekanisme pengaturan ginjal untuk perbedaan gender dalam tekanan darah dan mengeksplorasi efek dari asupan garam pada tekanan darah (sensitivitas garam) pada wanita pra dan pasca-menopause. Diperoleh hasil bahwa prevalensi garam-sensitivitas meningkat dengan usia dan diet rendah garam telah terbukti membantu mengurangi tekanan darah sistolik (SBP) dan diastolik BP. Sementara terapi hormon pengganti telah menghasilkan hanya efek netral atau minimal pada ketinggian tekanan darah sistolik (SBP).

Hal ini juga dijelaskan oleh Schulman \& Raij (2006) bahwa pada wanita setelah menopause, kejadian hipertensi meningkat ke tingkat yang sama atau melebihi pada pria, hal ini menunjukkan peran protektif dari hormon seks wanita. Sensitivitas garam terhadap tekanan darah dikaitkan dengan peningkatan risiko pengembangan hipertensi dan penyakit kardiovaskular. Beberapa penelitian telah menunjukkan bahwa setelah menopause, prevalensi sensitivitas garam meningkat, menunjukkan bahwa hormon seks perempuan (esterogen) mempengaruhi penanganan natrium pada ginjal dan regulasi tekanan darah.

Menurut Katsilambros (2011) uji acak terkontrol kepada penderita hipertensi menunjukkan bahwa penurunan asupan natrium sebesar 80-100 mmol (4,7-5,8 g natrium klorida) perhari dari asupan awal sebesar $180 \mathrm{mmol}$ (10,5 g natrium klorida) perhari mampu mengurangi tekanan darah rata-rata sebesar 4-6 $\mathrm{mmHg}$.

\section{Analisis Deskriptif Korelasi Antara Stres, Aktivitas Fisik, Asupan Lemak, Dan Asupan Natrium Terhadap Hipertensi Pada Usia Menopause}

\section{Analisis Multivatriat}

Hasil analisis multivariat terhadap 4 variabel bebas dalam penelitian ini yaitu variabel stres, aktivitas fisik, asupan lemak, dan asupan natrium. Uji regresi logistik ganda menunjukkan bahwa hanya satu variabel asupan natrium yang paling dominan mempengaruhi hipertensi pada usia menopause. 
Natrium dan kalium mengatur keseimbangan asam basa darah, mengatur keseimbangan cairan dalam tubuh, mengatur kontraksi otot-otot, dan merangsang fungsi syaraf. Natrium juga mengatur agar garam-garam mineral lain larut dalam darah supaya jangan mengendap pada dinding pembuluh darah (Lean, 2006).

Natrium terutama terdapat dalam cairan di luar sel seperticairan dalam pembuluh darah dan cairan dalam jaringan di antara sel-sel.Garam dapur mengandung natrium yang dibutuhkan oleh tubuh untuk menjalankan fungsi tubuh. Ginjal akan menahan natrium saat tubuh kekurangan natrium dan sebaliknya saat kadar natrium tinggi, ginjal akan mengeluarkan kelebihan natrium melalui urin. apabila fungsi ginjal tidak optimal, kelebihan natrium tidak bisa dibuang dan menumpuk di dalam darah. Volume cairan tubuh akan meningkat dan membuat jantung dan pembuluh darah bekerja lebih keras untukmemompa darah, tekanan darah pun akhirnya meningkat (Almatsier, 2009).

Pengaruh asupan garam terhadap timbulnya hipertensi terjadi melalui peningkatan volume plasma, curah jantung, dan tekanan darah. Keadaan ini akan diikuti oleh peningkatan ekskresi berlebih garam, sehingga kembali kepada keadaan hemodinamik yang normal. Pada penderita hipertensi esensial mekanisme ini terganggu, disamping adanya faktor lain yang berpengaruh (Soeparman, 2001).

\section{SIMPULAN DAN SARAN}

\section{Simpulan}

Dari hasil penelitian yang dijabarkan, maka dapat ditarik kesimpulan sebagai berikut:
1. Wanita menopause yang hipertensi sebagian besar mengalami stres sedang, aktivitas fisik dengan intensitas sedang, konsumsi makanan dengan asupan lemak yang lebih, dan asupan natrium yang lebih.

2. Ada hubungan antara stres dengan hipertensi pada usia menopause di Puskesmas Pangkalan Lada.

3. Ada hubungan antara aktivitas fisik dengan hipertensi pada usia menopause di Puskesmas Pangkalan Lada.

4. Ada hubungan antara asupan lemak dengan hipertensi pada usia menopause di Puskesmas Pangkalan Lada.

5. Ada hubungan antara asupan natrium dengan hipertensi pada usia menopause di Puskesmas Pangkalan Lada.

6. Berdasarkan hasil analisis multivariat diperoleh hasil hanya satu variabel asupan natrium yang paling dominan mempengaruhi hipertensi pada usia menopause.

\section{Saran}

\section{Bagi Peneliti Selanjutnya}

Hendaknya melakukan penelitian lebih mendalam terhadap variabel-variabel yang lain tentang hipertensi pada usia menopause dan faktor-faktor pencegahannya, sehingga dapat meningkatkan wawasan dan informasi masyarakat terhadap pencegahan dini terjadinya resiko hipertensi.

\section{Bagi Puskesmas}

Memberikan informasi ataupun penyuluhan-penyuluhan pada posyandu lansia tentang faktor-faktor penyebab terjadinya resiko hipertensi pada usia lanjut terutama untuk wanita yang telah memasuki usia menopause, sebagai upaya untuk pencegahan sejak dini 
terhadap hipertensi pada wanita menopause dengan pola hidup dan gaya hidup yang sehat. Sehingga dapat mengurangi angka kejadian hipertensi terutama pada wanita menopause.

DAFTAR PUSTAKA

Abernity, Kathy. (2002). The Menopause and HRT Second Edition. London: Bailliere Tindall.

Aburto, N. J., Ziolkovska, A., Hooper, L., Elliott, P., Cappuccio, F. P., \& Meerpohl, J. J. (2013). Effect of lower sodium intake on health: systematic review and metaanalyses. Bmj, 346(April), f1326.

Almatsier, Sunita. (2009). Prinsip Dasar Ilmu Gizi. Jakarta : Gramedia Pustaka Utama.

Andrews, Gilly. (2009). Buku Ajar Kesehatan Reproduksi Wanita (Women's Sexual Health). Addison Wesley Longman China Limited. Hong Kong GCC/02. Alih Bahasa, Sari Kurnianingsih. Jakarta: EGC.

Andria, K. M. (2013). Hubungan Antara Perilaku Olahraga, Stres, Dan Pola Makan Dengan Tingkat Hipertensi Pada Lanjut Usia di Kelurahan Putih Kecamatan Sukolilo Kota Surabaya. Jurnal Promkes, Vol. 1, No, 111-117.

Arikunto. (2006). Prosedur Penelitian Suatu Pendekatan Praktik. Jakarta: Rineka Cipta.

Baecke J.A.H, Burema, J. and Frijters, J.E.R. (1982). A Short Questionnaire for the Measurement of Habitual Physical Activity in Epidemilogical Studies.
American Journal of Clin Nurt. 36 : 936-942.

Bustan, Najib M. (2015). Epidemiologi Penyakit Tidak Menular. Jakarta : Rineka Cipta.

Chida, Y., \& Steptoe, A. (2010). Greater cardiovascular responses to laboratory mental stress are associated with poor subsequent cardiovascular risk status: A meta-analysis of prospective evidence. Hypertension, 55(4), 1026-1032.

Chaplin, J.P. (2000). Kamus Lengkap Psikologi. Jakarta : PT. Raja Grafindo Persada.

Chataut, J., Adhikari, R. K., \& Sinha, N. P. (2011). Prevalence and risk factors for hypertension in adults living in central development region of Nepal. Kathmandu University Medical Journal, 9(33), 13-18.

Corwin, Elisabeth J. (2000). Buku Saku Patofisiologi. Jakarta:EGC.

Depkes R.I.(2008). Profil Kesehatan Indonesia. Jakarta.

Dinkes Jateng. (2012). Profil Kesehatan Propinsi Jawa Tengah. Jawa Tengah.

Dinkes Semarang. (2014). Profil Kesehatan Kota Semarang . Semarang.

Douglas, Wetheril.M.S. (2001). Penyakit Jantung. Jakarta: Gramedia.

Fadi G. Hage, Sulaf J. Mansur, Dongqi Xing and Suzanne Oparil.

Fisman, E. Z., Tenenbaum, A., \& Pines, A. (2002). Systemic hypertension in postmenopausal 
women: a clinical approach. Current hypertension reports, 4(6), 464-470.

Fitriani, Anna. (2012). Kondisi Sosial Ekonomi dan Stres pada Wanita Hipertensi Anggota Majelis Taklim Social Economic and Stress Condition in Hipertension Women of Majelis.Jurnal Kesehatan Masyarakat Nasional Vol. 7, No. 5. Departemen Gizi Fakultas Kesehatan Masyarakat Universitas Indonesia.

Hawari D. Manajemen stres, cemas dan depresi. (2001). Jakarta Balai Penerbit Fakultas Kedokteran Universitas Indonesia.

Hidayat, A. (2011). Metodologi Penelitian Kebidanan dan Tenik Analisa Data. Jakarta:

Salemba Medika

Izumi $\mathrm{Y}$, Matsumoto $\mathrm{K}$, Ozawa $\mathrm{Y}$, Kasamaki Y, Shinndo A, Ohta M, Jumabay M, Nakayama T, Yokoyama E, Shimobukuro H, Kawamura H, Cheng Z, Ma Y, Mahmut M. (2007). Effect Of Age At Menopause On Blood Pressure In Postmenopausal Women. American Journal Hypertens; Volume20 (10): 1045-50.

Kaplan, Norman M \& Joseph, M.D. (2006). Kaplan's Clinical Hypertension (9th ed). USA:

Lippincontt Williams \& Wilkins.

Katsilambros, Nikolaos. (2011). Clinical Nutrition In Practice. Jakarta : EGC.

Kearney PM, Whelton M, Reynolds K, Muntner P, Whelton PK, He J. (2005). Global burden of hypertension: analysis of worldwide data. Lancet.;365:217-223.

Kemenkes RI. (2014). Hipertensi. Pusat Data dan Informasi Kementrian Kesehatan Republik Indonesia.

Kim, J.-M., Kim, T.-H., Lee, H.-H., Lee, S. H., \& Wang, T. (2014). Postmenopausal hypertension and sodium sensitivity. $J$ Menopausal Med, 20(1), 1-6.

Kotchen, Theodore A. (2006). Nutrition, Diet, and Hypertension. Modern Nutrition in Health and Disease (2). Philadelphia: Lippincot Williams \& Wilkins.

Lean, E.J Michael. (2006). Food Science, Nutrition \& Health. London :

Edward Arnold.

Lestari, Dian. (2010). Hubungan Asupan Kalium, Kalsium, Magnesium, dan Natrium, Indeks Massa Tubuh, serta Aktifitas Fisik dengan Kejadian Hipertensi pada Wanita Usia 30

- 40 Tahun. Skripsi. Program Study Ilmu Gizi Fakultas Kedokteran Universitas Diponegoro.

Lidyawati. (2014). Hubungan Asupan Asam Lemak Jenuh, Asam Lemak Tidak Jenuh Dan Natrium Dengan Kejadian Hipertensi Pada Wanita Menopause Di Kelurahan

Bojongsalaman.Artikel

Penelitian, 1-31. Skripsi. Program Studi Ilmu Gizi Fakultas KedokteranUniversitas DiponegoroSemarang.

Mannan, Hasrin, Wahiduddin, Rismayanti. (2012). Faktor 
Risiko Kejadian Hipertensi Di Wilayah Kerja Puskesmas Bangkala Kabupaten Jeneponto Tahun 2012.Epidemiologi Fakultas Kesehatan Masyarakat Universitas Hasanuddin.

Manuaba, Ida Bagus Gde. (2009).

Kesehatan Reproduksi Wanita.

Jakarta: EGC.

Muliyati, H., Syam, A., \& Sirajuddin, S. (2010). Hubungan Pola Konsumsi Natrium Dan Kalium Serta Aktifitas Fisik Dengan Kejadian Hipertensi Pada Pasien Rawat Jalan Di Rsup Dr. Wahidin Sudirohusodo Makassar. The Correlation of Dietary Pattern of Sodium , Potassium , and Physical Activity With the Suffered Hypertension of Outpatients in Rsup Dr. Wahidin Sudirohusodo. Media Gizi Masyarakat Indonesia, Vol.1,No.1,Agustus 2011 : 46-51

Notoatmodjo, Soekijo. (2005).

Metodologi Penelitian Kesehatan. Jakarta:Rineka Cipta

Nurmalina, Rina. (2011). Pencegahan \& Manajemen Obesitas. Bandung :Elex Media Komputindo.

Nuzzo, A., Rossi, R., \& Modena, M. G. (2010). Hypertension alone or related to the metabolic syndrome in postmenopausal women. Expert review of cardiovascular therapy, 8(11), 1541-1548.

Papalia, E.Diane. (2015). Experience Human Development 12th ed. Alih Bahasa: Fitriana Wuri

Herarti (Menyelami Perkembangan Manusia). Jakarta: Salemba Humanika.
Peremenkes (2014). Peraturan Menteri Kesehatan Republik Indonesia Nomor 41 Tentang Pedoman Gizi Seimbang.

Peter Kokkinos , Puneet Narayan , Andreas Pittaras, and Charles Faselis. (2016) . The Role Of Exercise And Physical Activity In The Prevention Of Hypertensive Heart Disease. Hypertension and Cardiovascular Disease. DOI 10.1007/978-3-319-39599-9_13.

Price, Sylvia A \& Lorraine M. Wilson. (2006). Patofisiologi Konsep Klinis Proses-Proses Penyakit. Jakarta:EGC.

Rahayu, Puji. D. (2014). Hubungan Usia Menopause Dengan Kejadian Hipertensi Di Desa Kutaliman Kecamatan Kedungbanteng Kabupaten Banyumas Tahun 2014. Jurnal

Kesehatan

Kusuma Husada. http://e-

journal.kusumahusada.ac.id/index .php/JKK/article/view/15/pdf_5.

Riskesdas. (2013). Riset Kesehatan Dasar. Badan Penelitian Dan Pengembangan Kesehatan Kementerian Kesehatan RI.

Rossi, R., Nuzzo, A., Origliani, G., \& Modena, M. G. (2008). Metabolic syndrome affects cardiovascular risk profile and response to treatment in hypertensive postmenopausal women. Hypertension, 52(5), 865-875.

Saryono. (2008). Metodologi Penelitian Kebidanan DIII, DIV, 
S1, dan S2. Yogyakarta: Mitra Cendikia.

Sase, Aprilindo.F. (2013). Hubungan Durasi Aktivitas Fisik dan Asupan Natrium Dengan Tekanan Darah Pada Wanita Menopause. Program Studi Ilmu Gizi Fakultas Kedokteran Universitas Diponegoro Semarang. http://eprints.undip.ac.id/39456/.

Schulman, I. H., \& Raij, L. (2006). Salt sensitivity and hypertension after menopause: Role of nitric oxide and angiotensin II. American Journal of Nephrology, 26(2), 170-180.

Sharma, Sanjay. (2015).

Hypertension with special reference to causes and diet. Indian Journal Of Applied Research. Volume : $5: 12$ ISSN - 2249-555X.

Sherman S. 2005. Defining the menopausal transition. The American journal of medicine; 118 :

3-7.

Sherwood L. Organ Endokrin Perifer. (2004). Dalam: Beatricia Santosa, editor. Fisiologi

Manusia: dari Sel ke Sistem. Ed. 14. Jakarta: EGC.

Smeth, Bart. (2004). Psikologi Kesehatan. Jakarta : Grafindo.

Soeparman. (2001). Ilmu Penyakit Dalam Jilid II. Jakarta : Balai Penerbit FK UI.

Son, M. K., Lim, N.-K., Lim, J.-Y., Cho, J., Chang, Y., Ryu, S., ... Park, H.-Y. (2015). Difference in blood pressure between early and late menopausal transition was significant in healthy Korean women. BMC Women's Health, 15(1), 64 .

Steptoe, A., \& Kivimaki, M. (2013). Stress and cardiovascular disease: an update on current knowledge. Annu Rev Public Health, 34, 337-354.

Steptoe, A., Kivimäki, M., Lowe, G., Rumley, A., \& Hamer, M. (2016). Blood Pressure and Fibrinogen Responses to Mental Stress as Predictors of Incident Hypertension over an 8-Year Period. Annals of Behavioral Medicine, 1-9.

Sugiyono. (2014). Metode Penelitian Kuantitatif Kualitatif dan $R \& D$. Bandung: Alfabeta.

Sugiyono. (2013). Statistika Untuk Penelitian. Bandung : Alfabeta.

Supariasa, I,. Bachyar, B., dan Ibnu, F. 2012. Penilaian Status Gizi. Jakarta: EGC.

Theodore L.G. (1983). Hypertension Essentials. Current Concepts of Cause and Control. New York: Grune \& Stratton.

Turky, K., Elnahas, N., \& Oruch, R. (2013). Effects of exercise training on postmenopausal hypertension: Implications on nitric oxide levels. Medical Journal of Malaysia, 68(6), 459464.

Wang, F., Tiwari, V. K., \& Wang, H. (2014). Risk Factors for Hypertension in India and China : a Comparative Study, 37, 40-49. 
Weiten, Wayne. 2012. Psychology:

Themes and Variations. USA:

Penerbit Wadsworth.

Widyaningrum, Siti (2012).

Hubungan Antara

Konsumsi Makanan

DenganKejadian

Hipertensi Pada

Lansia(Studi Di Upt

Pelayanan Sosial Lanjut

Usia Jember). Skripsi

Bagian Gizi Kesehatan

Masyarakat Fakultas

Kesehatan Masyarakat

Universitas Jember.

Wilmore, J. H. and Costill, D. L. (2004). Physiology of Sport and Exercise. Human Kinetics Publishers. United States of America.

Wijaya, Saferi A, dan Putri Mariza Y.

(2013). Keperawatan Medikal

Bedah 1. Yogyakarta :

Nuha Medika.

World Health Organization. (2013). A

global brief on

Hypertension.World Health Day.

World Health Organization.(2001). Hypertension Control.

(Diterjemahkan Prof. Dr.

Kosasih Padmawinata).

Bandung : ITB 